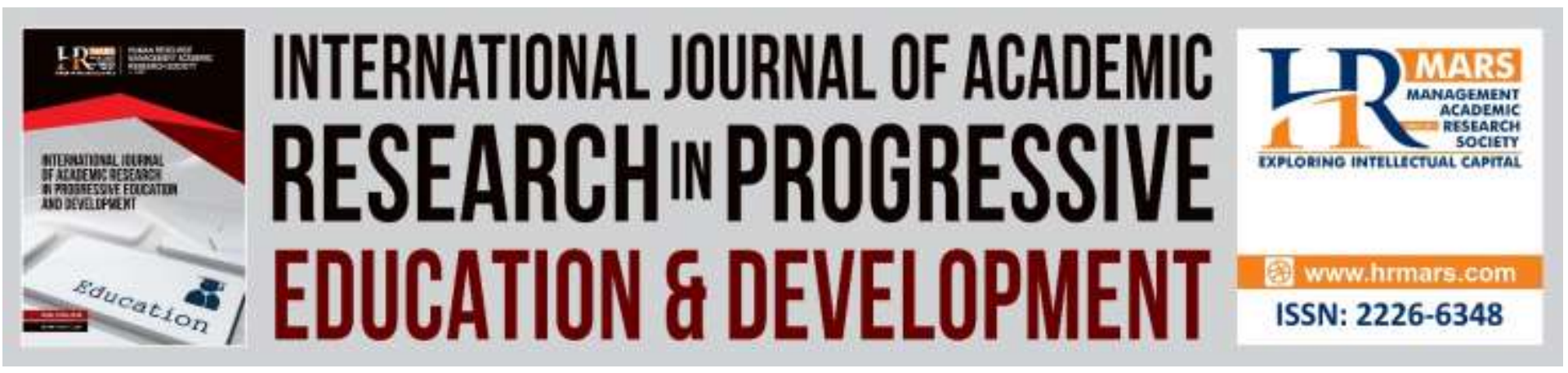

\title{
Methodology of Tajwid Knowledge Learning: Survey on Riwayah and Dirayah Aspects
}

\section{Azizul Bin Hassan, Wan Mohd Khairul Firdaus Wan Khairuldin, Mohd Norhafizi Bin Yusof}

To Link this Article: http://dx.doi.org/10.6007/IJARPED/v8-i2/5684

DOI: $10.6007 /$ IJARPED/v8-i2/5684

Received: 23 March 2019, Revised: 19 April 2019, Accepted: 29 April 2019

Published Online: 06 May 2019

In-Text Citation: (Hassan, Khairuldin, \& Yusof, 2019)

To Cite this Article: Hassan, A. Bin, Khairuldin, W. M. K. F. W., \& Yusof, M. N. Bin. (2019). Methodology of Tajwid Knowledge Learning: Survey on Riwayah and Dirayah Aspects. International Journal of Academic Research in Progressive Education and Development, 8(2), 113-124.

\section{Copyright: (C) 2019 The Author(s)}

Published by Human Resource Management Academic Research Society (www.hrmars.com)

This article is published under the Creative Commons Attribution (CC BY 4.0) license. Anyone may reproduce, distribute, translate and create derivative works of this article (for both commercial and non-commercial purposes), subject to full attribution to the original publication and authors. The full terms of this license may be seen

at: http://creativecommons.org/licences/by/4.0/legalcode

Vol. 8(2) 2019, Pg. 113 - 124

http://hrmars.com/index.php/pages/detail/IJARPED

JOURNAL HOMEPAGE

Full Terms \& Conditions of access and use can be found at http://hrmars.com/index.php/pages/detail/publication-ethics 




\title{
Methodology of Tajwid Knowledge Learning: Survey on Riwayah and Dirayah Aspects
}

\author{
Azizul Bin Hassan \\ Maahad Tahfiz Al-Quran Terengganu (MTQT)
Wan Mohd Khairul Firdaus Wan Khairuldin, Mohd Norhafizi Bin Yusof \\ Universiti Sultan Zainal Abidin (UniSZA)
}

\begin{abstract}
Urge and suggestion that every al-Quran reciter needs to ensure that the recitation complies with Tajwid methods, is a sunnatullah which is obligatory to be obeyed. This is because Al-Quran is a tauqifiyah ritual which is encouraged in Islam. Therefore, aspects of narration based on Talaqqi \& Musyafahah methods have been prioritised since the event of first revelation descent. Clearly, this method has proved that Al-Quran recitation is continuously guarded and any form of recitation which is not narrated should be rejected even though it is spoken by some of Arabic community based on their daily dialect. However, after the era of earliest Islamic scholars has passed, then alQuran recitation is beginning to be seen as undergoing changes due to revolving time and era. Besides that, clarity and accuracy of the recitation could not be evaluated bu accurate method due to several factors and some of them become polemic in the community without a comprehensive mechanism of solution. Thus, to visualise back the method of tajwid based on method of prophet and salaf scholars, this tiny paper tries to focus the building of understanding in learning Tajwid knowledge accurately based on integration between riwayah and dirayah elements. Hopefully, the existence of this concise discussion would pose positive impact in implementing the understanding of Fiqh Al-Tajwid concretely.
\end{abstract}

Keywords: Tajwid, Knowledge, Learning, Riwayah, Dirayah.

Introduction

Al-Quran narration is a sunnatullah towards the guarding and sustenance of Al-Quran. It is a manifestation to promise of Allah SWT through His words:

$$
\text { جָ }
$$

Meaning: "Truly, we are the one who descended Al-Zikr (Al-Quran) and We are the guardian of it" 
According to Habannakah (2012), this verse is a strong proof of Al-Quran guarding by Allah SWT from any alteration. It was revealed to answer the suspicion of Arab Jahiliyah that created doubt to the authenticity of Al-Quran if Prophet SAW deceased and the effort of creating a worry to Muslim community by imagining the situation when the earth is governed by a person besides Prophet who is not infallible. Thus, this verse is the comprehensive answer to the doubt. This verse also elaborates that the guarding aspect encompasses various topics such as its interpretation, law and pronouncement.

So, among the main elements to be emphasised towards Al-Quran is by ensuring that its pronouncement is conformed accurately. This matter is paid attention particularly high by the past Islamic scholars through discipline of knowledge known as Tajwid. Hence, Islamic scholars agreed that Al-Quran is read with a specific method revealed to Prophet SAW, and then is descended to the generation of Companions RA, and then to generation of Tabi'in and then to the generation of Qurra' imams whom their accuracy of recitation is acknowledged. Their carefulness towards this matter is by observing the important aspects in the recitation such as the diacritic, pharyngealisation, attributes of the letter and others. They have propagated the recitation of AlQuran with carefulness and trust that it will be conformed as the recitation of Prophet SAW.

Recitation of Al-Quran is a ritual encouraged to every Muslim and bestowed with multiples of reward. This recommendation comes clearly through words of Allah SWT:

$$
\text { جث }
$$

Meaning: "Read the easy one for us from the verses of Al-Quran"

Any form of ritual revealed to Prophet SAW is in the tauqifiy form in which its method of practice is explained accurately. It is also like other forms of ritual taught by Prophet SAW such as nasalisation, lengthening, letter pronunciation and others (Farghaliy, 2012). For example, صلوا كما رأيتموني (a) explanation for the practical aspect of prayer is through hadith of Prophet SAW (Bukhari, 2002), the practical aspect of pilgrimage is through hadith (خذو أصني مناسككم) (alBaihaqi, 2003)., while the practical aspect of Quranic recitation is through similar form of commandments such as:

I. Hadith riwayat Ibn Mas'ud RA:

$$
\text { (قال علي بن أبي طالب إن رسول الله صلى الله عليه وسلم يأمركم أن تقرؤو اكما علمتر) }
$$

Meaning: "Ali Bin Abi Talib RA said that Rasulullah SAW commanded to you that you read (al-Quran) as how you are taught" (al-Baihaqi, 2003).

II. Riwayat 'Urwah Ibn Zubair RA:

$$
\text { (إنما القر اعة سنة من السنن فاقرؤوه كما علمنموه () }
$$

Meaning: "Truly, recitation (of Al-Quran) is a sunnah the sunnahs of Prophet SAW, so recite is as how you are taught" (al-Baihaqi, 2003). 
The two narrations clearly emphasise the obligatory apsect of conforming the accuracy of recitation as taught by Jibril AS to Prophet SAW. The word (علمتموه) or (علمتم) signifies lucidly that recitation of Al-Quran cannot be performed merely according to the reciter's desire. Indeed, it must be guided by a teacher taking the recitation with a sanad (citation) from Prophet SAW (Farghaliy, 2012).

According to Nasr (2002), the strongest evidence relating the obligation of tajwid in the recitation of Al-Quran is a hadith narrated by Ibnu Mas'ud RA (al-Tabraniy, 1994) while he was observing the

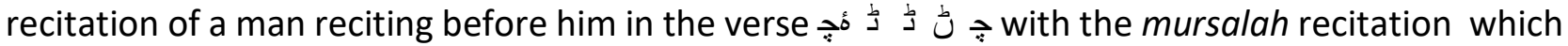
is the recitation without lengthening (in the word h $)$ ). Thus, Ibnu Mas'ud RA said: 'Prophet SAW has never taught me that kind of recitation'. Then the man said: 'How does Prophet SAW teach you

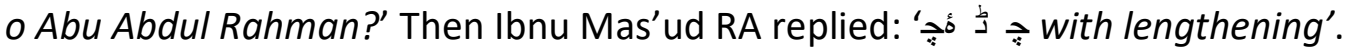

Ibnu Al-Jazariy (1999) also commented on the hadith as a clear evidence of the tajwid obligation. This statement is also supported by Abdul Fattah Al-Mirsafiy by explaining that the strictness showed by Ibnu Mas'ud RA in reproving the recitation for not conforming with the sunnah of recitation from Nabi SAW even though the recitation either with the lengthening or without it does not affect the meaning of the word (Al-Mirsafiy, ${ }^{\text {n.d.). }}$.

Therefore, it is a compulsion to every Muslim to follow the method of Tajwid in the recitation of Al-Quran. The recitation can be attuned by learning Tajwid knowledge practically and theoretically in a holistic way. This is because Prophet SAW received the recitation from Jibril AS completely from all aspects including the recitation method (Suwaid, 2018).

\section{The Accuracy of Al-Quran Recitation}

It is not undeniable that Al-Quran transmitted to recent generation is a result of reception by teacher through a citation linked to Prophet SAW. It becomes an effective weapon in ensuring that every recitation is conformed as the one received Prophet SAW from Jibril AS.

However, the recitation taken verbally can change and its authenticity is hard to be verified especially in this contemporary era. This can be witnessed in the contradicting matters happening in the recitation and its explanation by some of Islamic scholars either through verbal or written narration. The arising question is that if every contradicting party claims that their recitation is the most accurate by referring to the citation received from their teacher through 'Talaqqi and Musyafahah", then which recitation is authentic and which is not? That is the same case if every party is arguing by bringing forward sources from different references, then which source has the highest authority of verifying the authenticity of claim? What is the guarantee that can be posed to believe in every practical of recitation by attaching significant and concrete argument?

Those questions are basic elements which need to be revised by contemporary Islamic scholars. This is relevant as the issue regarding the accuracy of recitation arises the era far from the time of Prophet SAW and the best three generations which are the time of Companions RA, Tabi'in and Tabi' Tabi'in. Even though at that time the aspect of recitation reception only focused on 
INTERNATIONAL JOURNAL OF ACADEMIC RESEARCH IN PROGRESSIVE EDUCATION AND DEVELOPMENT

Vol. 8, No. 2, 2019, E-ISSN: 2226-6348 @ 2019 HRMARS

memorisation, they still follow the teaching of Prophet SAW without compromise especially in AlQuran recitation. This is because they are 'Arab Aqhah' group who do not need any correction of recitation and their purity and fluency is recognised, indeed the 'contamination of recitation' began to be detected due to the mingling of Muslim community from different backgrounds and races (Suwaid, 2018).

Al-Mar'asyi had reminded that the main factor to the change of a recitation by Masyaikh Al-Quran in this recent era is in view of time distance which is far from the time of Prophet SAW. Hence, it is irrelevant of assigning a teacher as the deciding proof to every recitation, and indeed, it is a need for the student to compare the recitation received from the teacher with the written explanation through books of scholars. If the recitation contradicts the scholars' explanation, then the teacher's recitation must be abandoned and the student must hold to the explanation by the books (AlMar'asyi, 2001). Besides that, (Farghaliy, 2012) also explained that the change of verbal recitation happens on account of Arabic language progress following the evolving time and this phenomenon worries the researcher in the Arabic phonetics field and scholars of Al-Qiraat. This worry is strongly relevant as if there is no method that can provide solution to the arising problem, then it could not be explained accurately and comprehensively. Moreover, according to Muhammad Hasan Jabal, argument based on talaqqi and citation is not ultimate, indeed the argument should first fulfill several conditions in ensuring the strength of evidence in supporting the recitation related to the talaqqi (Jabal, 2014). However, the argument also applies to the generation of companion, Tabiin, Arabs in the first and second century as they received the recitation in the most accurate and careful form without any doubt.

Among the factors contributing to the confusion in the argument of recitation is the mixing of information in the references of Tajwid books. According to Farghaliy (2012), there are many information related to Tajwid filled in contemporary works undergoing mixing of information between the explanation based on riwayah and personal ijtihad of the scholar. According to Ghanim (2009), he opined that the mixing of information in the dirayah (theoretical) explanation of Tajwid knowledge is caused by deficiency of access in referring to the books written by Islamic scholars in the salaf era. Moreover, these important works mostly are have not been studied yet by the researcher. Besides that, uslub and writing style which are oriented to summary are also a main cause of ignorance on the detailed elaborations in the recent Tajwid books. Then, attitude of some Quranic teachers who only take for granted with only several references based on recent summary books also complicates the explanation of the situation (Farghaliy, 2012).

Thus, it is understood that the two main factors leading to inaccuracy of recitation either verbal or written form argument have caused the occurrence of difference from the theoretical and practical aspects. The referred difference is the difference related to the cause of change in voice sound or known as khilaf muktabar. Therefore, a concrete mechanism needs to be formed to ensure that every information related to recitation of Al-Quran is detailed that it may not create confusion among the community. 
INTERNATIONAL JOURNAL OF ACADEMIC RESEARCH IN PROGRESSIVE EDUCATION AND

DEVELOPMENT

Vol. 8, No. 2, 2019, E-ISSN: 2226-6348 @ 2019 HRMARS

\section{Concept of Talaqqi \& Musyafahah}

In early generation, Al-Quran was taken in riwayah through Talaqqi and Musyafahah method from Prophet SAW utilising sama' (السماع) dan Aradh (العرض) methods. These methods were practicals of Prophet SAW before Jibril AS every year in the month of Ramadhan and in the decease year of Prophet SAW, it happened twice known as 'Al-'Ardhah Al-Akhirah' event. This event is important to be known as it is the main reference in extracting al-Quran from its various aspects of knowledge. Al-Quran is the most complete heavenly holy book and was revealed with its compplete method of recitation to the leader of all Prophets SAW and was revealed to the best people. Therefore, realising the fact, then beginning from the companion generation until scholars today, they have paid a high attention to this matter. They narrated the recitation of Al-Quran carefully without compromising even a letter. According to Al-Sakhawi (1987), Qurra' of salaf generation showed the recitation example and taught it to the students based on recitation of Prophet SAW completely which is as how Prophet SAW received it from Jibril AS from its aspect of Tajwid and recitation.

Nevertheless, the concept of Talaqqi \& Musyafahah used by the teachers of Al-Quran should be elaborated that it is not made arbitrarily a proof of reference to a recitation. To explain the real concept of this method, then elaboration by Al-Ja'bariy can be paid attention. He explained that Talaqqi \& Musyafahah consist of two main components which are haqiqi taqdiri. Haqiqi means the accuracy of pronouncing a sound which is the pronouncement recited by the student complying with the teacher's recitation. Meanwhile, taqdiri means the explanation of a recited pronouncement in the form of elaboration that can visualise the recitation accurately (al-Ja'bariy, 1999). This concept is also detailed by Ibn Al-Jazariy (1999) by applying the term Maqru' and Marwiy or Mantuq and Maktub. The sign of this method has already existed since the time of Prophet SAW in which the narration delivered by Prophet SAW was in verbal form and added with scripture element for each revealed verse until it was forbidden to scribe except for Al-Quran.

In the past generation, the explanation was performed verbally and with the strength of memory which Allah SWT bestowed upon them, the received recitation was transmitted properly. Every reciter receiving recitation from the teacher could recite as what was taught. However, realising the fact that each time will pass by and begin to spread away from the time of prophethood, then among the scholars, it began to exist those who bound the elaboration of the recitation in written form known as Tajwid knowledge. With the beginning of work binding era, it strengthens the real meaning of Talaqqi and Musyafahah which have always been referred for a certain recitation. So, mantuq is a receiving process of recitation for the student from the tteacher orally and it is also known as Riwayah. Meanwhile, Maktub is the explanation of the recitation recorded by the scholars in written form and it is known as Dirayah knowledge.

Therefore, it can be concluded that the real concept regarding Talaqqi and musyafahah methods is compulsory to integrate the two elements at once which are orally and in written form. Should only one element is utilised, then the method is still not complete and will result in vague understanding to the theory compiled by the scholars. To achieve a clear comprehension regarding 
INTERNATIONAL JOURNAL OF ACADEMIC RESEARCH IN PROGRESSIVE EDUCATION AND DEVELOPMENT

Vol. 8, No. 2, 2019, E-ISSN: 2226-6348 @ 2019 HRMARS

riwayah and dirayah, it is necessary to understand the form of both concepts as the following explanation:

i. Riwayah:

This concept is more famous in discipline of hadith as explained by Al-Suyuti (n.d.) regarding riwayah of hadith knowledge. It means, a certain knowledge explaining the word and action of Prophet SAW, the narration is accurate and detailed in the pronouncement aspect. Then the same concept if it is resembled to Tajwid knowledge is how the pronunciation of Al-Quran is conformed verbally. To conform to riwayah aspect in the taking and reception of Quranic recitation, then the scholars lined two main methods derived from the action of Prophet SAW:

a. Al-'Aradh:

Literally, it means meeting or encounter (Ibn Manzur, 2003). Meanwhile, from the aspect of Qurra term, it means the student's recitation before the teacher (al-Qustolaniy, 2003). This method is taken resulting from the event of recitation by Prophet SAW before Jibril AS (Al-Bukhariy, 2003). It was also done the companions RA such as Ibnu Mas'ud RA and Mujahid from among the Tabi'in (Al-Bukhariy, ${ }^{2003)}$. Al-Qustolaniy (2003) described that this method is the best method and practised by Qurra from salaf generation until now. This is because through this method, student is taught holistically from every aspect to ensure that the practical recitation achieves Prophet's standard.

b. Al-Sama':

Literally, it means listening and observing something from the hearing sense (IbnManzur, 2003). Meanwhile, technically it means observation and focus of Prophet SAW while listening to recitation of Jibril AS. This method is also taken from the event of presentation by Prophet SAW and the event when Allah SWT reproved Prophet that he should not hasten while listening to revelation by Jibril AS (al-Bukhariy, 2003).

Both methods derive from action of Prophet SAW. Therefore, integration of both methods in the narration of Al-Quran is very appropriate as it involves two-way teaching. It is an imitation from the great method by making example of the greatest teacher of the heaven who is Jibril AS and the best student of the earth who is Prophet SAW.

ii. Dirayah:

Dirayah knowledge is the complement in explaining the meaning of riwayah. It also becomes the benchmark to every information delivered verbally by referring to authorised sources through the binding of works by Islamic scholars. According to Jabal (2014), dirayah means the understanding of an explanation completely and in details and also the ability to comprehend its implicit meaning. Thus, absolutely, to gain a concrete comprehension on a certain knowledge, its elaboration should be examined holistically. He lined several importances of mastering dirayah knowledge properly, which are:

a. Gaining detailed understanding clearly and not though incomprehensible memorisation or known as the term 'babghai'. 
b. Dirayah knowledge also gives space for somebody to master the theory properly until he is recognised as expert according to his expertise.

c. Through this knowledge, it can visualise the mistakes which are difficult to be detected by public and correct them with significant evidence.

d. Dirayah knowledge is recognised as the essence of knowledge. Without it, a person would not be recognised as an expert of his field (Jabal, 2014).

In reality, the importance of mastering the dirayah knowledge has been paid attention by the past scholars. Among the scholars who emphasised this aspect is as following:

- Ibnu Mujahid (Deceased 324H):

He did not use the word dirayah clearly, but the matter being paid attention regarding the qualities of a good Imam of Qiraat signifies the importance of mastering dirayah knowledge. The mentioned qualities such as mastering of knowledge of Arabic language and its branches, mastering of sanad (citation) knowledge, and ability to differentiate an authentic and weak recitation (IbnMujahid, 1980).

- Abu Amru Al-Daniy (Deceased 444H):

He reminded that Qurra' possess their own level of knowledge. Some of the m master the knowledge properly, some only receive the knowledge merely by taqlid without any understanding. He also stressed that dirayah is the supporting proof for the reception of recitation through riwayah (al-Daniy, 1999).

- Makkiy Bin Abi Talib (Deceased 437H):

The same reminder as Al-Daniy (1999) was explained by Imam Makkiy regarding the matter. He emphasised that every reciter of Al-Quran at every level should also master dirayah knowledge.

- Abu Al-Qasim Al-Huzaliy: (Deceased 465H):

He classified the Qurra by stating that there are some of them who only understand the practical of recitation through riwayah and strengthened from dirayah aspect of Arabic language knowledge (Ibn al-Jazariy, 1999).

- Abu Al-Ala Al-Hamazaniy (Deceased 569H):

He explained on hidden mistakes performed by many of Al-Quran reciters. The mistakes could not be detected and known by public except after the process of Talaqqi and musyafahah. This process also must be taken from a skillful teacher from the aspect of riwayah and also dirayah such as the explanation of mad, limit of imalah pronunciation, ikhtilas and others (Al-Hamazaniy, 2005).

- Al-Zarkasyi (Deceased 794H):

$\mathrm{He}$ also stressed that the taking of Al-Quran recitation must be from the teachers who master two aspects which are riwayah and dirayah (al-Zarkasyi, n.d). 
Therefore, to sustain the knowledge among the teachers and students, it is necessary that the dirayah aspect is given a high attention. Efforts of boosting up attempts to the strengthening of this aspect is should be increased by doing research to the great works of salafi scholars either to the one already researched or still in the form of manuscript.

Until now, there are hundreds of books explaining Tajwid knowledge in various forms and elaborations that become the main references. The next question, what is the authorised source and can be regarded as the main source?

It becomes a need for every teacher, student and researcher of Tajwid knowledge to know the sources of Tajwid knowledge. This is due to the fact that by knowing the sources, someone could carry Tajwid knowledge clearly and visibly to the community. Reality nowadays is that the nonchalance that encompasses majority of the teachers and students has separated us from the original source of the knowledge derivation. Therefore, many of us are still not clear of what they learn. As a result, the delivered knowledge does not hit the target accurately and indeed most of them ar built on bases of logic and understanding which are not guided by correct method.

Guideline of tajwid is a worship to Allah SWT. As other forms of worship, this knowledge is obligatory of having concrete reference. Thus, it is necessary that every reciter recognises the used sources in explaining the knowledge. To understand and go deeper into this knowledge, scholars have divided the references into two sources which are:

\section{i. Original Source (primary);}

This source refers to the main source in the reception of tajwid knowledge. Initially, it came in the form of verbal narration and then in the form of writings by authorised scholars in salaf time. The writings which are necessary to be referred encompass scholars in Arabic language and Quranic field such as Al-Khalil (w 175h), Sibawaih (w 180h), Ibn Mujahid (w 324h), Abu Muzahim AlKhaqaniy (w 325h), Al-Daniy (w 444h), Makkiy (437h), Al-Qurtubiy (w 461h), Al-Syatibiy (w 590h), Al-Sakhawiy (w 643h) and Ibnu Jazariy (w 833h) (Jabal, 2014). Among them are salaf scholars who are recognised by Prophet SAW as the best generation. Meanwhile, some others are the continuity of methodology by salaf scholars until the time of Ibn Al-Jazariy. The supported methodology by them is the main methodology to be followed as they possess the advantage which cannot be achieved by other generations after them. Besides that many hadiths explaining the matter, scholars also posed additional commentary on it such as in the work of Ibn Rejab Al-Hanbaliy (2011) titled (فضل علم السلف عل علم الخلف). Al-Daniy (1999) also emphasised the same subject as his saying in Al-Arjuzah Al-Munabbahah:

$$
\begin{aligned}
& \text { ومن تر اه يحتذي الطريقا*****قدعه والزم يا أخي الصدوقا } \\
& \text { أولي النهى و العلم بالخلاف *****ريق من مضى من الأسلاف }
\end{aligned}
$$

He provided a guide on talaqqi and reminded to take same path as the one of slaafi scholars.

Al-Andalusiy (2005) also reminded the same:

$$
\text { "فاثر ع أيها القارئ بما رسمت للك في هذا الإنباء فإنه قطب يدور عليه توقيف أئمة الأداء" }
$$


INTERNATIONAL JOURNAL OF ACADEMIC RESEARCH IN PROGRESSIVE EDUCATION AND DEVELOPMENT

Vol. 8, No. 2, 2019, E-ISSN: 2226-6348 @ 2019 HRMARS

If the reminder is looked carefully, it can be understood clearly that the explanation contained in book of Al-Inba' is the result of narration in verbal form. The sign is obvious through the usage of the word (توقيف أئمة الأداء) and then forbad reciters of Al-Quran from performing any ijtihad.

\section{ii. Second Source (secondary);}

This source refers to supporting source in the taking of Tajwid knowledge. It refers to any writing published after the time of Ibnu Al-Jazariy (Farghaliy, 2002). History dictated that scholars after him still retained the method of mutaqaddimin scholars until the $11^{\text {th }}$ century when Tajwid books were infiltrated with ijtihad element (Zallath, 2014). Habash (2014) also stressed the ijtihad aspect in recitation of al-Quran through his saying that:

$$
\text { "أن باب الاجتهاد منقطع تماما فيما يتعلق برو اية القرءان -تناوته و أدائه" }
$$

Al-Quran derives from the revelation of Allah SWT, thus definitely its method of recitation cannot be contaminated with ijtihad element as it complies with usul al-figh ( لا إجتهاد مع نص) method.

Besides that, the enthusiasm of knowledge seekers declines each day as they prefer to study simple, light and easy books. As a result, many confusions arise in the explanation of the knowledge until contradictions occur in the recitation such as the pronunciation of Iqlab, tafkhim \& tarqiq and others that need for detailed and comprehensive explanations by the scholars.

\section{Conclusion}

Generally, the basis of receiving Al-Quran recitation which is obligatory to be undergone is through presenting the recitation before the teacher. However, if there any contradiction happening to a certain recitation, then the reference to the explanation through books of scholars is critically needed. It is advised that each referred source is ensured in which the primary source is prioritized, and if it comes from the secondary source and the explanation complies with the explanation and method of mutaqaddimin scholars, then it is valid to be referred. If there is any contradiction between contemporary and mutaqaddimin scholars, then the view coming from mutaqaddimin scholars is obliatory to be prioritised. And should there is any contradiction between mutaqaddimin scholars themselves, then the view hold by the majority of scholars is prioritised without blaming the minority view.

Makkiy (2009) put a clear method regarding the matter in his saying:

$$
\begin{aligned}
& \text { "و الرواية إذا أتت بالنص في الكتب و القر اءة كانت أقوى وأولى من رواية لم تنقل في كتاب، و لا صحبها نص. وما نقل بتلاوة ولم } \\
& \text { يؤيده نص كتاب فالو هم و الغلط ممكن من نقله؛ إذ هو بشر التها..." }
\end{aligned}
$$

He explained that a verbal narration supported by explanation of scholars is stronger as a proof, meanwhile if anything happens differently, the recitation should be examined in deeper manner as it is possible that mistakes happen in the narration caused by human which is exposed to making of mistakes.

Hence, as a reminder and guide, riwayat from Al-Sya'biy (al-Tabraniy, 1994) can also be attended:

$$
\text { "القر اءة سنة فاقرؤو ا كما قر أ أولوكم" }
$$


INTERNATIONAL JOURNAL OF ACADEMIC RESEARCH IN PROGRESSIVE EDUCATION AND DEVELOPMENT

Vol. 8, No. 2, 2019, E-ISSN: 2226-6348 @ 2019 HRMARS

Meaning: "Al-Quran recitation is a sunnah, thus recite it as the recitation of previous generation before you"

Therefore, this clear method can be made a benchmark to every arising problem regarding Tajwid knowledge. Hopefully, this tiny article would bring a new paradigm in the teaching and learning of Tajwid knowledge to reciters of Al-Quran.

\section{Corresponding Author}

Wan Mohd Khairul Firdaus Wan Khairuldin, Universiti Sultan Zainal Abidin, Malaysia.

Email: wanfirdaus@unisza.edu.my

\section{References}

Habannakah, A.R. (2012). Ma'arij Al-Tafkir Wa Daqaiq Al-Tadabbur, Damsyik: Dar Al-Qalam.

Al-Daniy, A.A. (2009). Al-Tahdid Fi San'ah Al-Itqan Wa Al-Tajwid, Al-Qahirah: Maktabah Aulad AlSyeikh.

Suwaid, A. (2018). Talaqqi Al-Quran, Dar Al-Ghauthaniy.

Al-Baihaqiy. (2003). Al-Sunan Al-Kubra, Beirut: Dar Al-Kutub Al-'Ilmiyyah.

Al-Bukhariy. (2002). Sahih Al-Bukhariy, Beirut: Dar Ibn Kathir.

Al-Daniy, (1999). Al-Arjuzah Al-Munabbah, Riyadh: Dar Al-Mughniy.

Al-Hakim. (2002). Al-Mustadrak, Beirut: Dar Al-Kutub Al-Ilmiyyah.

Al-Hamazaniy (2005). Al-Tamhid, Al-Qahirah: Dar Al-Sahabah.

Al-Ja'bariy, (1999). Kanz Al-Ma'aniy, Al-Madinah: Universiti Islam Madinah.

Al-Mar'asyi. (2001). Juhd Al-Muqil, Amman: Dar Ammar.

Al-Mirsafiy, (n.d). Hidayatul Qari, Al-Madinah Al-Munawarrah: Maktabah Toyyibah.

Al-Qustolaniy. (2013). Lathaif Al-Isyarat, Arab Saudi: Mujammak Malik Fahd.

Al-Sakhawiy (1987). Jamal Al-Qurra', Makkah: Maktabah Al-Turath.

Al-Suyuti. (n.d). Tadrib Al-Rawiy, Dar Toyyibah.

Al-Tabraniy (1994). Al-Mu'jam Al-Kabir, Maktabah Ibn Taimiyah.

Al-Zarkasyi. (n.d). Al-Burhan, Al-Qahirah: Maktabah Dar al-Turath.

Farghaliy, (2012). Al-Itqan, Maktabah Al-Syeikh Farghaliy.

Ghanim, Q.H. (2009). Al-Dirasat Al-Sautiyyah 'Inda Ulama Al-Tajwid, Jordan: Dar Ammar.

Ibn a-Jazariy. (1999). Munjid Al-Muqri'in, Beirut: Dar Al-Kutub Al-IImiyyah/

Al-Hanbaliy, I.R. (2011). Fadhl Ilm Al-Salaf, Saudi: Dar Al-nafais.

Ibn Taimiah. (2005). Al-Ubudiyyah, Beirut: Al-Maktab Al-Islamiy.

Ibnu Al-Jazari. (2018) Al-Nasyr, Beirut, Lubnan: Dar Al-Ghauthaniy.

Ibnu Al-Tahhan.(2005). Al-Inba' Fi Tajwid Al-Quran, Al-Qahirah: Al-Maktab Al-Islamiy.

Ibn Manzur. (2003). Lisan al-Arab, Al-Qahirah: Dar Al-Hadith.

Ibn Mujahid. (1980). Al-Sab'ah, Mesir: Dar Al-Ma'arif.

Khairuldin, W.M.K.F.W., Embong, A.H., Anas, W.N.I.W.N., Mohd, H. \& Ismail, D. (2018), The Application of Technology in the Dissemination of Fatwas: A Study on Religious Institutions in Malaysia, International Journal of Civil Engineering and Technology, 9(7), 2018, pp. 15901596. 
Khairuldin, W.M.K.F.W., Ismail, D., Anas, W.N.I.W.N., Ibrahim, I., \& Fauzi, N. (2016). Freedom of Speeches by Mufti According to Islam: Implication to Fatwa in Malaysia. International Journal of Academic Research in Business and Social Sciences. 6 (12). Pp 141-151.

Khairuldin, W.M.K.F.W. (2016). Konsep Fatwa dalam Islam. Kuala Terengganu: Penerbit UniSZA.

Khairuldin, W. M. K. F. W., Anas, W. N. I. W. N., \& Embong, A. H. (2018). Fatwa as a Disseminator of Islamic Laws among Community of Malaysia. International Journal of Academic Research in Business and Social Sciences, 8(11), 516-521.

Khairuldin, W.M. K. F. W. (2018). Fatwa Role in Education and Legal Dispute in Malaysia. International Journal of Academic Research in Progressive Education and Development, 7(4), 295-302.

Khairuldin, W. M. K. F. W., Anas, W. N. I. W. N., \& Embong, A. H. (2018). The Binding of Laws to Personal Opinion of Muftis in Malaysia. International Journal of Academic Research in Business and Social Sciences, 8(11), 522-529.

Khairuldin, W. M. K. F. W., Embong, A. H., Anas, W. N. I. W. N., Ismail, D., \& Mokhtar, W. K. A.W. (2019). An Augmented Reality (AR) Approach in Educational Integration of Du'a in Islam. International Journal of Academic Research in Progressive Education and Development, 8(1), 32-39.

Khairuldin, W. M. K. F. W., Embong, A. H., \& Anas, W. N. I. W. N. (2019). Technological Approach in Education of Musafir (Muslim Traveler) in Islam: The Study on Mobile App Mysafar. International Journal of Academic Research in Progressive Education and Development, 8(1), 40-47.

Zallath, M.R. (2014). Aisar Al-Turuq, Al-Qahirah: Dar Al-Sahabah.

Yasin, M.F.M., Embong, A.H., Khairuldin, W.M.K.F.W., Rahim, R.S.A., Abdullah, A., Said, S. \& Mutalib, N.A. (2018). Contributions of Technology Towards Development Of Qur'anic Tajweed Knowledge, International Journal of Civil Engineering and Technology, 9(6), 2018, pp. 1340-1352

Makkiy, A.T. (2009). Al-Ri'ayah Li Tajwid Al-Qira'ah, Al-Qahirah: Maktabah Aulad Al-Syeikh.

Habash, M. (2014). Al-Qiraat Al-Mutawatirah, Al-Qahirah: Dar Al-Sahabah.

Jabal, M.H. (2014). Al-Talaqqi Wa Al-Ada Fi Al-Qiraat Al-Qur'aniyyah', Al-Qahirah: Maktabah AlAdab.

Nasr, M.M. (2002). Al-Qaul Al-Mufid, Jordan: Jam'iyyah tahfiz Al-Quran, Second Edition $2002 \mathrm{M} / 1422 \mathrm{H}$. 